\title{
Impact on Temple Missions and Roles in the COVID-19 Situation: A Case Study of Phra Nakhon Si Ayutthaya Province
}

\author{
Phrapalad Raphin Buddhisaro (Duangloi) ${ }^{1}$,Direk Duangloy ${ }^{2}$, Lampong Klomkul ${ }^{3}$, Mallika \\ Phumathon Duangloy ${ }^{4}$ \\ ${ }^{1,2,4}$ Mahachulalongkornrajavidyalaya University, \\ ${ }^{3}$ Rajaphat Nakornsawan University \\ Email: ${ }^{1,2,4}$ raphind@yahoo.com, ${ }^{3}$ research.mcu@gmail.com
}

\begin{abstract}
The purpose of this research article was to study impacts on missions and the roles of temples in the COVID-19 situation of the Sangha, Phra Nakhon Si Ayutthaya Province. Mixed methods research was designed. Quantitative research using survey research method was conducted. Data were collected by using online questionnaires through google form tool from monks of 450 temples in Phra Nakhon Si Ayutthaya province. For qualitative research, in-depth interview and online participatory observation were collected during April - May 2020. Results indicated that impacts on the mission of the Sangha in Phra Nakhon Si Ayutthaya Province were shown (1) in respect of ceremonies and rituals temples cannot perform monastic religious and ceremonies under the anti-COVID-19 social distancing policy such as chanting, praying, receive food offerings. For related religion ceremonies such as ordination, weddings, death and general merit making that aiming for the spiritual support of Buddhists, cannot be carried out. (2) For impact on the administration of monastic affairs, online meeting was used for the administration and management. (3) Roles of the measure in the COVID-19 situation, the temple and the supreme rulers of the Sangha have implemented a policy to help society through setting up a restaurant during difficult times, distribute items, consumer goods, food, water and subsistence. At the national level, Phra Nakhon Si Ayutthaya Province Sangha distributed items to facilitate people. (4) Missionary mission by communicating patience, beliefs and principles for self-tolerance via online system which consisted of Facebook, YouTube, Zoom to stay at home to prevent COVID-19 with government agencies for achieving holistic results in managing COVID-19 prevention.
\end{abstract}

Keywords

Missions and Roles of Temples, COVID-19 Situation, Phra Nakhon Si Ayutthaya

Article Received: 10 August 2020, Revised: 25 October 2020, Accepted: 18 November 2020

\section{Introduction}

In a research study on Coronavirus (COVID-19) outbreak in Thailand [1] that provided information on the coronavirus (COVID-19) outbreak, it was found in Thailand since 13 January 2020, with Thailand being the first confirmed case outside the country. China then began surveillance of those arriving from China. In February still found a small number of patients confirmed about 35 later found that more cases. In the middle of March by spreading the infection in a large group that found many patients from Lumpini Boxing Stadium and entertainment venues from the Thonglor area Then, one week later, the country found a situation of confirmed patients more than 100 people per day, causing the government to declare the state of emergency on March 26, 2020 and to prohibit leaving the housing during the night from 3 April 2020 onwards, and in a research paper on Clinical practice guideline for management of spinal fracture and spinal disease in the pandemic of COVID-19 [2]. The data reflected some of that "The spread of disease is rapid in many areas, posing a threat to people's well-being and damaging the global economy," or in the research "Balance of organizational well-being management" [3] reflecting to "policy setting establish measures to prevent and cope with the spread of the COVID-19 virus, including in the research paper "Coronavirus infectious disease-2019 (COVID-19): a case report, the first patient in Thailand and outside China." [4] that reflect information "... the first case of COVID 19 in Thailand and outside China. As a Chinese female tourist high fever was detected at 38.6 degrees
Celsius at Suvarnabhumi airport ... "or in a research paper" Learning Organization: The Challenges of Knowledge Management in the Changing Paradigm" [5] that provides information "Knowledge management in the learning organization in the paradigm of changes in bring knowledge and ability to help the organization through a crisis... " based on information appearing on the educated clergy work. In this study, the overall study of the Sangha in Ayutthaya Province was conducted. It reflects the impact on the administration of temples and Buddhist affairs, and manage the faith of the people and the role that contributes to society in the current situation of COVID-19.

\section{Research Objectives}

The purpose of this research article was to study impacts on missions and the roles of temples in the COVID-19 situation of the Sangha, Phra Nakhon Si Ayutthaya Province.

\section{Research Conceptual Framework}

Conceptual framework of the study on "Impact on temple missions and roles in the Covid-19 situation: a case study of Phra Nakhon Si Ayutthaya Province can be shown as below figure. 


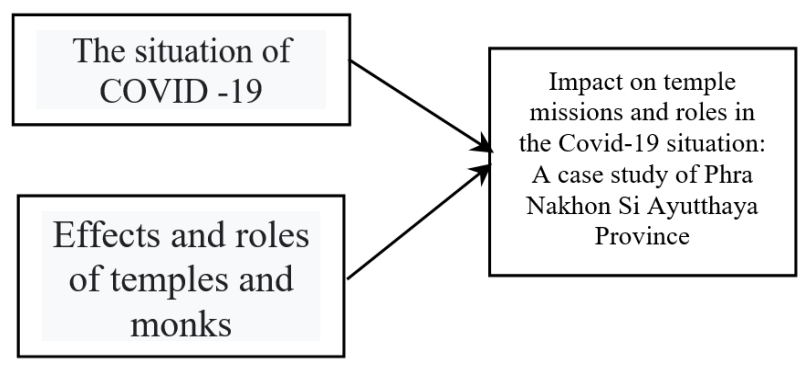

Fig. 1 Conceptual Framework

\section{Research Method}

This research is Participatory Action Research (PAR) by indepth interview 10 key informants, focus group discussion with 11 experts and quantitative research. From a simple sampling of temples with activities and data can be accessed via a specific online questionnaire system in 41 temples with activities helping people from 507 temples in Phra Nakhon Si Ayutthaya province. Questionnaires in the online system Google Form was used for data collection and analyze the qualitative data by focusing on the impact on temples, monks, people and their roles in Phra Nakhon Si Ayutthaya Province.

\section{Results}

From research studies to impact on the mission and role of temples in the COVID-19 situation: a case study of Phra Nakhon Si Ayutthaya Province, the study found as below:

1. Impact on the mission of temples, monks and Buddhists in Phra Nakhon Si Ayutthaya Province that can be classified as following items.

(1) Effects on the routine of monks and novices living according to the principles of Dhamma and discipline, religious traditions, such as meditation, chanting, alms, going to prosper, Buddhist pray, celebrate faith of the Buddhists in the house activities due to merit and traditions were implicitly canceled. It is the lifestyle of the novice monks as it turns out, a picture of the news of the fear of COVID-19. Ayutthaya Sangha Order do not fling nagasprinkling alms. Novice monks are required to wear masks [6] or from interviews with the deputy priest of Phra Nakhon Si Ayutthaya Province regarding the impact on the novice monks who have information on the activities of the monks and other. All affected are the same in every measure which had to sustain himself in this difficult situation together [7].

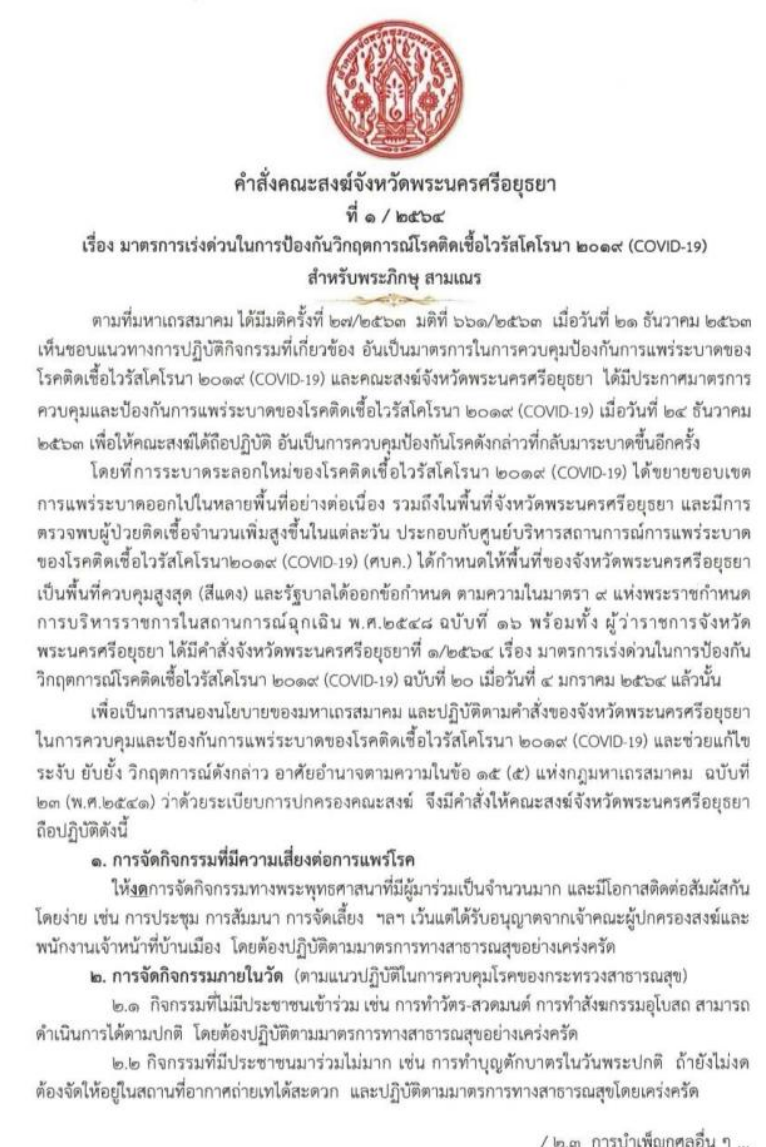

Fig. 2 Order of the Sangha Priest on the Measures of the Epidemic in the prohibition of monastic activities and wearing a mask according to government measures (Source: Watpanancheng Ayutthaya, January 2020) (in Thai)

(2) Impact on the practice of the Dharma and ritual religion means impact on the monks who are required to perform their duties according to the Dharma. When government agencies have established measures in regard to spacing and prohibiting any gatherings to meet among many people measures responded to the measure or government policies. Therefore, affecting the monks who have to perform routines such as chanting, rebuilding, chanting the Patimokkha, other monastic activities, spacing measures refraining from performing ordinances, such as the abolition of ordination, abolition of mass-attended cremation, the termination of various merit-making ceremonies, the abstention of people from using services at the temple for all religious-related activities. Thus, it will affect the income of the temple that comes with the donation of the people which affects the cost of water, electricity and other expenses within the temple, including construction education administration [8].

(3) Effects on the administration of the Sangha Affairs is a mission due to the administration of the Sangha both in terms of education management, both Dharma and Pali education, monks and novices in educational institutions must stop. The administration of the Sangha in accordance with the framework of the work, such as government, education, welfare must be stopped or postponed. At the 
same time, the Sangha and temple have found a channel or other means to manage such as organizing an online meeting, sending work orders via e-mail system, sending via group line in the management of faculties Sangha in Phra Nakhon Si Ayutthaya Province [9].

(4) Impact on the people who use the temple services in Buddhism in terms of Buddhist activities, worshiping monks, and tourism of temples in Ayutthaya that are archaeological sites and tourism including doing activities due to Buddhism [10].

(5) Reflection, assistance or demands of the temple and the affected people. The surveyed temples and monks will present a request to the government, for example, to help temples and communities in the event of a shortage of certain areas to promote the knowledge of self-defense through advising on how to prevent and maintain correct health, free from risks [11] and protect yourself. The temple is the center or channel of communication between government agencies and Buddhist aid resources, [12] the abolition of water and electricity bills to help and alleviate difficulties in the COVID-19 situation [13].

The role of temples and monks on people in the situation of COVID-19 in Phra Nakhon Si Ayutthaya Province.

From a survey research study, it was found that the monks had the role to society and the community in the broader picture of Ayutthaya Province. It is the province that has been affected like other provinces according to the measures and guidelines that appear.

(1) Role in establishing a temple as a almshouse to provide assistance to people in distress and low income, having cooked food during social spaced situations and unable to pursue a career.

(2) The role of being the center in providing assistance to the people in which temples and monks have established a donation center to assist people in consumer goods, rice, dry food and necessary utensils, such as masks, washing gel, to prevent the spread of COVID-19.

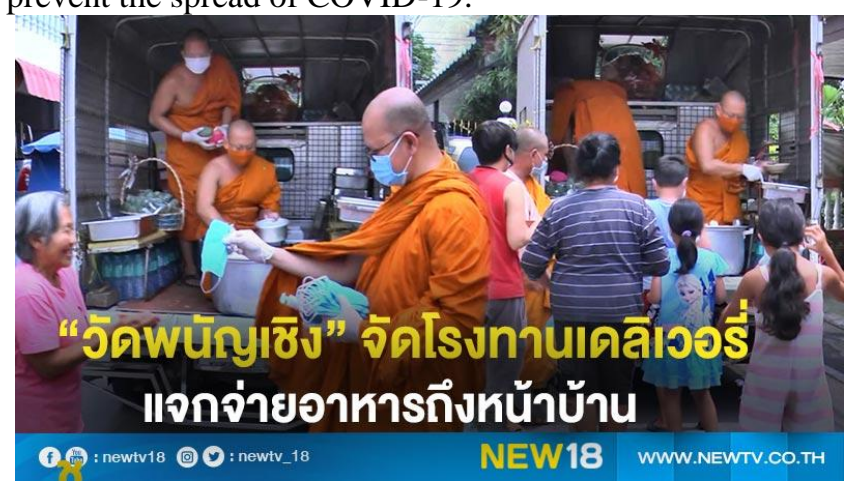

Fig.3 Temples in Phra Nakhon Si Ayutthaya Province has established a cooked dining hall distributed to people in the community area near the temple.

(Source: Watphanancheng, Ayutthaya, 20 June 2020).

(3) The role of being the center in providing assistance to the people in which temples and monks have established a donation center to assist people in consumer goods, rice, dry food. And necessary utensils, such as masks, washing gel, to prevent the spread of COVID-19.
(4) Role in community modeling in promoting sufficiency under difficult circumstances. Buddhism has principles or the concept of patience including promoting temples in Phra Nakhon Si Ayutthaya Province as food production sites that is to use the free space as a food production source create a garden for agriculture, grow organic vegetables to use as a cooking appliance and distribute to people in the temple area or nearby temple [14].

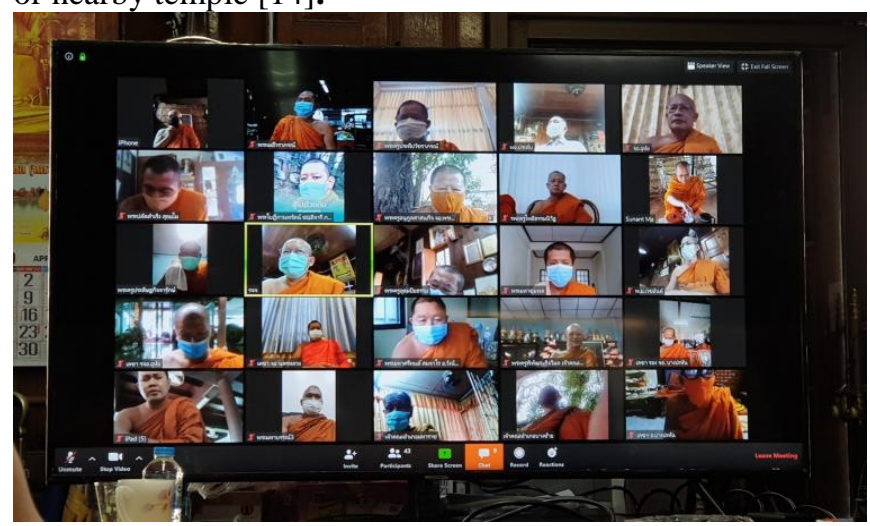

Fig. 4 Effects on the monks in the administration of the

clergy have a meeting through online system to help each other and help people in the COVID situation

(Source: Watphannancheng, Ayuthaya, 30 ${ }^{\text {th }}$ June 2020)
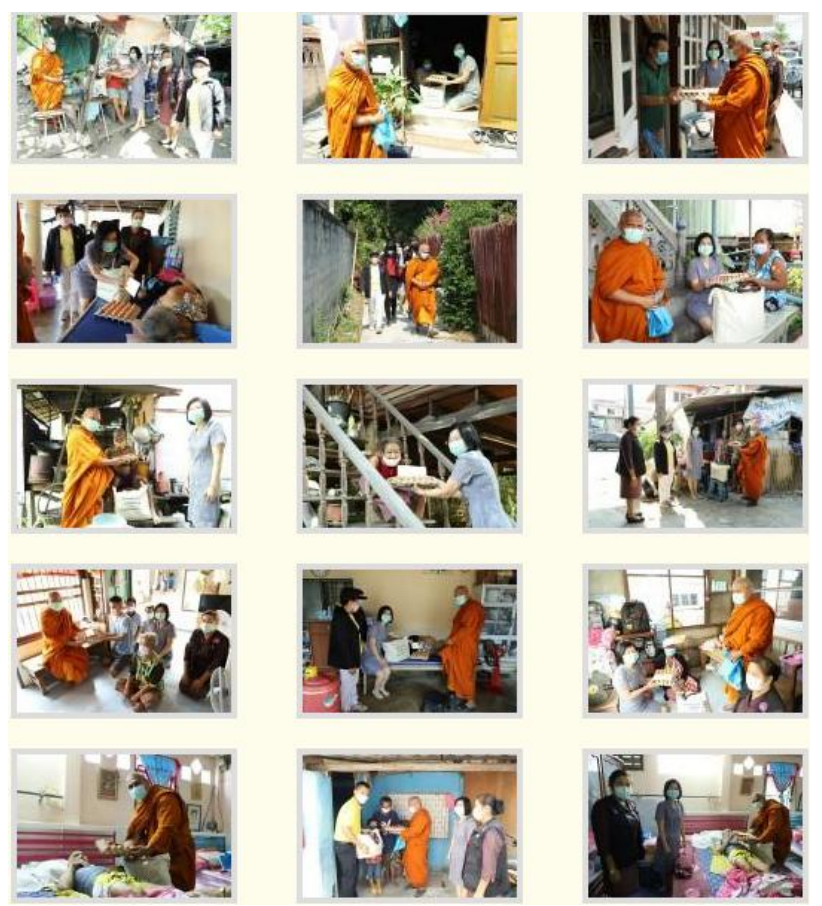

Fig. 5 Roles of temples and monks in Phra Nakhon Si Ayutthaya Province have established a diner to distribute cooked food and give away consumables consuming for bed-bound patients

(Source: Watyaichaimongkol Ayutthaya, 30 June 2020)

From Fig. 5, reflecting the role of monks in Phra Nakhon Si Ayutthaya province under the situation of COVID which includes roles in social work helping within the framework of public welfare work helping to share food, rice, water, or fostering the creation of food sources planting vegetables in a kitchen garden to distribute to people in the temple area the preparation of cooked food for daily consumption by 
bringing dried rice to the public visiting a bed-bound patient in a lockdown situation that cannot go anywhere.

\section{Discussions}

Studies have shown about the role of monks in the situation of the COVID-19 epidemic in Thailand especially in the area of Phra Nakhon Si Ayutthaya Province to do its job of treating and fostering a reactive effect on this difficult situation.

1. Temples and monks and Buddhists as a whole were affected the same throughout the country. Whether it is the ritual effect of the monks to act as one's own religion, to carry out the religious path the impact on people in reaching religious sites and performing their duties as Buddhists are all different. This is in line with the article on Covid-19 crisis affect social change [15] that reflects the results of the study on how the COVID-19 situation affects poverty. Social inequality including economic stagnation and society as a whole or in the research on COVID-19 management 6 Mission - COVID-19, Management of 6 Mission on Buddhist Administration [16] that proposed the concept of temple management. Buddhism under the circumstances which emphasizes the need for adaptation and use of technology communication is used in the administration of Buddhism as well.

2. Impact on the implementation of the roles of the monks on the administration of Buddhism, meaning the monks have to adjust in the administration of the Sangha both in terms of administrative administration and educational Administration. Part of the role of teaching and learning in the classroom was terminated. Administrative administration that requires a meeting have an online meeting. The use of various technologies to assist in the administration of ecclesiastical affairs in line with the research on Coronavirus Disease 2019 (COVID-19) Problems and leadership potential for New Normal Organization Development [17] that reflects in all situations. Everything has to adjust to accommodate the changes that occur to drive the organization or management to have practical results in this difficult situation as well. This is in line with the research entitled "New Normal" A new way of life and adaptation of Thai people after COVID-19: Work Education and Business [18] and adjustment and cooperation in the COVID-19 Virus Situation by according in Buddhism [19]. Proposed is the concept that adaptation to new situations is very important and necessary.

3. The role of monks and temples in providing assistance to society and people in the wake of the COVID-19 epidemic remains an important role and continued to do so from the past to the present to provide assistance to alleviate suffering of the people according to the burden of the Sangha in the public welfare. According to a research paper entitled The Role of Monks in Helping the people in the Covid 19 Situation [20], it provides information that in the current state, people's lives have been largely changed due to the problem of the Coronavirus epidemic COVID-19 causing the lives of the people to struggle even more it is therefore necessary to have a responsible person and find a way to help people who have suffered in the situation that arise. Monks, as part of society, had to bring the crisis in this situation as an opportunity to help society, to provide relief for the people and is an important part to help alleviate suffering for people who have been suffering, such as helping to donate food, drinking water, masks to make society live happily are generous for each other. Therefore, the role of the monks is essential to make society happier, or in a research paper entitled The Role of Monks in Public Welfare Under the Pandemic of COVID-19 Virus: A Case Study of Luang Por Daeng Nantthiyo's Role, Intharam Monastery, Samut Songkhram Province [21] reflecting that monks still play an important role in Public welfare providing assistance to people, communities and society as well that the temple has social capital and has the potential to help (alms) sacrifice (ja) to benefit the public. As in the case of Luang Por Daeng donated mask, gel, food Preserve, refrigerator, happiness establishment of alms donate funds to help people, temples, monks, government agencies. Educational institutions at the local level is the temple and the community and at the district level Samut Songkhram Province and the national level, which is a response to the Supreme Patriarch's policy in setting up a almshouse to help people and provide items, food appliances, rice, disinfectant dispenser for Mahachulalongkornrajavidyalaya University Amphawa Hospital to support the management under the situation of COVID-19 to pass through, Dharma heals the mind, home visits, online lectures, is another role for monks to work in public welfare in Thailand that monks still play a role in society in various fields especially in the public sector, providing assistance in the event of the COVID-19 epidemic during the current situation.

\section{Body Of Knowledge From Research}

From research studies can be written as a figure about the situation of the temple and the monks in the current situation that can be defined and brought to public communication.

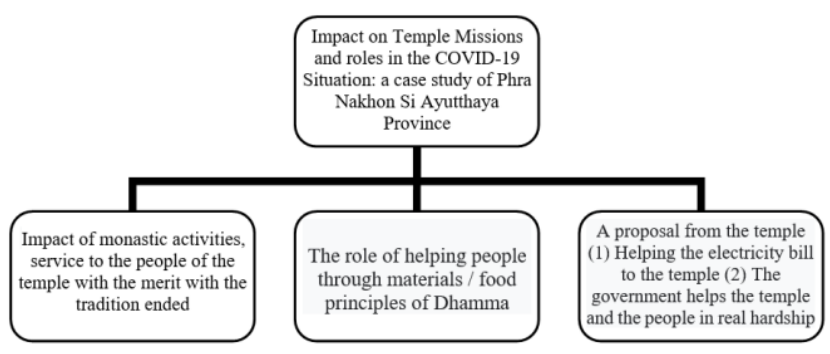

Fig. 6 Body of Knowledge from research

From Fig.6 provides information into 2 cases of effects on customs routines such as prayer and alms which are monastic activities. Effects of the administration of the Sangha administration in the area effects on the administration of society and people such as monks ordination, merit making, keeping precepts. In the part of temples and monks, it caused the monks to help people in the distribution of supplies in terms of principles showing morals, encouragement, strengthening the mental potential in difficult situations in order to keep moving forward with Facebook live, Youtube Dhamma Channel, Banner Dhamma or other channels in the system. All online for the benefit of religious communication are from temples and monks to people. 


\section{Recommendations}

\section{Recommendations for Policy}

1) Policy should be promoted to allow temples and monks to create more roles in society and people through activities, or other projects under the circumstances that continue to spread until now.

2) The government sector should promote a governmental model, operating as a center for helping people in the difficult situation of the epidemic of COVID.

\section{Recommendations for further research}

1) Research should be conducted on the role of monks in providing assistance to society and people in the situation of COVID-19 that is occurring in Thailand since the new year 2011.

2) Research should be conducted about measures for the administration of the monastic affairs in various areas, especially regarding the adjustment of temples and monks in the current second round of the coronavirus situation.

\section{Conclusion}

The situation of COVID-19, people in the holistic body of Thailand in the first outbreak affected by social spacing. According to the state, strong measures is issued to control and shut down the country in holistic situation. Therefore, affected that it is no different when specific to Phra Nakhon Si Ayutthaya Province. It showed that temples and monks were affected in a holistic, not much different. But as Phra Nakhon Si Ayutthaya Province is a large province, there are more than 496 temples scattered in various communities that facilitates and provides convenience to the people.

\section{References}

[1] S. Chokkhanchidchai, Coronavirus (COVID-19) outbreak in Thailand. Journal of Preventive Medicine Association of Thailand, 10(1), January-April 2020: 1.

[2] T. Sornsa-ard, W. Liewrungreung, Clinical practice guideline for management of Spinal fracture and Spinal disease in the pandemic of COVID-19, Journal of Nakornping Hospital, 10 (2), JulyDecember 2019: 59-73.

[3] Phrakhru Kowitbunkhet, Amnaj Thapin, Balance of organizational well-being management. Journal of MCU Buddhapanya Review, 5(1), 2020: 182189.

[4] A. Ratnarathon, Coronavirus infectious disease-2019 (COVID-19): a case report, the first patient in Thailand and outside China, Journal of Bamrasnaradura Infectious Diseases Institute,14(2), MayAugust 2020: E11-8 https://he01.tcithaijo.org/index.php/bamrasjournal/article/ view/241494/164620

[5] K. Kankaew and others, Learning Organization: The Challenges of Knowledge Management in the Changing Paradigm, Journal of Legal Entity Management and Local Innovation, 6 (2), March-April, 2020:22242-254.

[6] Reporter, Fear of COVID! Ayutthaya Sangha Order Do not fling nagasprinkling alms. Novice monks must wear masks, Newspaper Matichon, Online, 5 January 2021. https://www.matichon.co.th/region/news_2 514856

[7] Phramethivaraporn, Vice-Chief of Provincial Monks Administration of Ayutthaya,Interviews.15 January

2021.

[8] Phraman Bun Panyatharo,Vice-Abbot Watyaichaimongkol, Interview, June 30, 2020.

[9] Interviewer 1, Abbot of Temple in

Ayutthaya, Interview, January 15, 2021.

[10] Interviewer 2, Abbot of Temple in Ayutthaya, Interview, January 15, 2021.

[11] Interviewer 3, Abbot of Temple in Ayutthaya, Interview, January 13, 2021.

[12] Interviewer 4, Abbot of Temple in Ayutthaya, Interview, January 9, 2021.

[13] Interviewer 5, Abbot of Temple in Ayutthaya, Interview, January 11, 2021.

[14] Interviewer 6, Abbot of Temple in Ayutthaya, Interview, January 7, 2021.

[15] S. Chobpradit, COVID-19 Crisis Affect Social Change, Journal of Chaiyaphum Review, 3(2), May-Augus 2020: 1-14.

[16] Phrasamu Amorn Paphakaro, Phra Chaisith Kittipanyo. COVID-19, Management of 6 Mission on Buddhist 
Administration. Buddhism for peace Journal, 1(1) January-June, 2020:74-85.

[17] B. Thongthip, Coronavirus Disease 2019 (COVID-19) Problems and Leadership Potential for New Normal Organization Development, Journal of Social Science and Buddhistic Anthropology, 5 (11), November 2020:434-447.

[18] T. Sangsawangwatthana and Others, "New Normal" A new way of life and adaptation of Thai people after Covid-19: Work Education and Business. Journal of Local Governance and Innovation. 4 (3), September-December 2020: 263-278. https://so03.tci-

thaijo.org/index.php/JLGISRRU/article/vi ew/243943

[19] T. Kerdkaew, Adjusment and Cooperation in the Covid 19 Virus Situation by According in Buddism. Journal of Graduate Studies Reviews 16(2),MayAugust 2020:59-78. https://so02.tcithaijo.org/index.php/JGSR/article/view/24 2870

[20] Phra Natthawut Phanthali. The Role of Monks in Helping the People in The Covid 19 Situation,Saeng Isan Academic Journal, 17(2) January-June 2020: 66-76.

[21] Phra Ekkalak Achito and Others. The Role of Monks in Public Welfare Under the Pandemic of Covid 19 Virus : A Case Study of Luang Por Daeng Nantthiyo's Role, Intharam Monastery, Samu Songkhram Province.Journal of MCU Social Science Review . 9 (3), July September 2020;289-304. 